\title{
WELLCOME MUSEUMS AT THE ROYAL COLLEGE OF SURGEONS
}

$\mathrm{T}$ THE Wellcome Museums of the Royal College of Surgeons of England were formally opened on November 20 by Sir Henry Dale, chairman of the Wellcome Trustees. The ceremony took place in the Great Hall of the College, situated immediately beneath the Museums, and the gift was accepted on behalf of the College by the president, Sir Harry Platt.

The erection of the Museums has been made possible by a generous gift of $£ 100,000$ to the College by the Wellcome Trustees. The grant was made in recognition of the service which the College has rendered not only to surgery but also to a much wider range of medical and scientific knowledge by the maintenance of its historic and world-famous museums of human and comparative anatomy and pathology. In accordance with the terms of the Trust, the grant was "for the foundation or extension of Museums dealing with medical science or research", a description which was in accordance with the policy of the College Council, which has for long regarded its museums and research laboratories as complementary to each other.

The further condition that the name of Wellcome should be associated with the Museums was one with which the College was happy to comply, for the late Sir Henry Wellcome was an honorary fellow of the College.

The Museums are contained in the south-eastern part of the College, the first part to be rebuilt and enlarged after war damage in 1941. They are situated on the second, third and fourth floors, lying immediately above the Great Hall and coinciding with it in area. The general plan is the same on each floor, the main area (about five-sevenths) forming the exhibition room and the remainder being devoted to research and work-rooms connected with the respective museum functions. Adjacent are the other parts of the College's Departments of Pathology and Anatomy, with their research laboratories and (yet to be built) demonstration rooms. Thus on each floor the Wellcome Museum forms an integral part of the department, the threefold activities of which, dealing with museum, research and teaching, are co-ordinated by the Sir William Collins professor of human and comparative anatomy and conservator of the Anatomical Museum and by the Sir William Collins professor of human and comparative pathology and conservator of the Pathological Museum.

On the second floor the approach is through the research rooms of the Department of Pathology and the offices of the conservator (Prof. G. J. Cunningham). The Wellcome rooms begin with the office of the pathology curator (Dr. L. W. Proger), adjacent to which is a research laboratory and opposite is a museum preparation room and workshop. The exhibition room itself shows the layout intended for all three museums, namely, five bays along either side of the room, each containing specimen shelves on three sides and a table and chairs for study in the centre. The central aisle of the room can be laid out with floor stands or left free for temporary exhibitions. 'Natural' fluorescent lighting has been provided, and this with the neutral grey background displays the colour of the specimens to best advan. tage.

The present collection is made up of specimens surviving war damage, together with more recent additions. The specimens are arranged in lettered sections according to systems: $\mathrm{S}$, skeletal; $\mathrm{A}$, alimentary; etc. Catalogues with descriptions, clinical and histological notes are provided, and reference to histological slides may be made if required. In suitable cases, photomicrographs, X-rays or clinical photographs are mounted with the specimen to complete the pathological picture. Future progress with this collection involves improving quality, extending the series of exhibits and making good deficiencies.

On the third floor the approach is similarly through the research rooms of the Department of Pathology, though the rooms on this floor are temporarily let to the Imperial Cancer Research Fund as biochemical laboratories. The Wellcome rooms on the third floor start with the photographic studio unit and a large museum store. In the exhibition room the arrangement of the shelves at the near end is similar to that of the room below, while at the farther end a space has been partitioned off, by agreement with the Wellcome Trustees, as a demonstration room for students taking the Basic Medical Sciences course. This is a temporary arrangement, pending completion of the next phase of rebuilding the College, and the whole room will be devoted to the exhibition of specimens within the space of two or three years.

The present exhibits include the Teratology Section and selections from the Odontological Collection, the War Gollection, and Hunterian Collection. On completion of the next phase of the rebuilding programme, this room will be devoted to a museum illustrating the general principles of pathology. In this collection provision will be made to supplement the specimens with photographs, charts and diagrams.

The fourth floor forms a part of the Department of Anatomy, and here again the approach is through the research rooms and the offices of the conservator (Prof. G. W. Causey). As on the other floors, the Wellcome rooms are reached just before the exhibition room and include a workshop and mounting room, an embalming and preparation room and a prosectors' room. The roorn at present used for prosectors is destined eventually to become the curator's room.

The exhibition room itself, the Museum of Anatomy and Physiology, is eventually to be laid out with bays on very much the same plan as that of the second floor. Meanwhile, however, the Wellcome Trustees have generously agreed to accommodate the College during its rebuilding by allowing demonstrations to be held in the Museum. Two rooms have therefore been formed by the erection of light partitions, and steel shelving has been put up as a temporary arrangement on all the available wall space.

The first part of the exhibition room contains the Hunterian Physiological and Comparative Anatomical Collection that will be ultimately housed in the rebuilt west end of the College. The far end of the 
exhibition room contains the human anatomical specimens that will later be arranged in cubicles covering different systems, illustrated by suitable tracings and diagrams of selected physiological and pharmacological reactions.

These new Museums occupy nearly the same site as the rooms which were destroyed by enemy action in 1941, though they are at a higher level and are more economical of space, each occupying one com. plete story, compared with the nineteenth-century rooms which consisted of a floor and two galleries.

\section{THE NATIONAL LEATHERSELLERS COLLEGE}

\author{
By DR. J. P. DANBY \\ Principal
}

$\mathrm{O}^{\mathrm{s}}$ November 15, the Minister of Education opened extensions at the National Leathersellers College in Bermondsey, London, S.E.1. These consist of a three-story wing housing now research laboratories, a lecture theatre and a senior common room, and drying rooms for heavy and light leather, together with a single-story block consisting of yards for the preliminary and tanning processes for both heavy and light leather manufacture. Moreover, the additional space provided has facilitated the reequipment and modernization of the original building, which is now almost fifty years old.

The College was founded and built in 1909 by the Worshipful Company of Leathersellers, following the success of the courses in leather manufacture which had been given since $\mathbf{1 8 9 5}$ at the Herolds Institute. During these years, rapid developments were taking place in the field of leather chemistry, and it was becoming apparent that the subject merited individual facilities for training and research. The appreciation of fundamental principles underlying the processes of a craft industry by men such as Procter, Stiasny and Knapp was raising leather manufacture from a craft to a science, with the consequence that a rapid expansion took place in the demand for men with a scientific training by tanners all over the world.

Between 1909 and 1951 the Leathersellers Technical College became recognized throughout the world. as one of the leading institutions in this sphere of instruction, and under three successive principals gained a wide reputation for the training of technologists in the leather industry. However, although improvements and additions to the College were made from time to time, it was inevitable that sooner or later major developments would be necessary if the College were to maintain its place in the advance of technological education. Consequently, when the Minister of Education, following the recommendations of the Percy Report, decided to found a number of colleges with national status to accommodate the educational noeds of the smaller industries, the leather industry approached him with the request that the Leathersellers College should be reconstituted as the National College for the Leather Industry. A trust deed was drawn up, a widely representative board of governors was appointed, and the National College came into being in September 1951. Shortly afterwards, plans were drawn up to extend and re-equip the College, and this has now been done at a cost of more than $£ 90,000$, a part of which has been provided by the industry itself. In consequence, there is little doubt that the College is now one of the finest of its kind in the world.

Since the tanner's raw material is animal skins, the technology of leather manufacture is based on protein chemistry. At the same time, because of the variety of other materials used in the manufacturing processes, a trained technologist must possess some knowledge of a wider range of both natural and synthetic products than is called for by almost any other industry, and the subject has therefore some connexion with all the main branches of pure, and many aspects of applied, chemistry. From the practical point of view also, the range of leathers in common use necessitates, in a teaching institution, facilities for their manufacture from the raw skin to the finished product. Further, some familiarity with the ancillary subjects becomes necessary in so far as they impinge on both the theoretical and practical aspects of the principal study.

The scientific and practical approaches have always been the foundations of the College courses; although in the past the training has been more squarely based on processes than on theory, the latter has by no means been neglected. However, the advances which have been made in fundamental knowledge and its systematization, and the development of new techniques, now demand a far more exhaustive course than it has been possible to provide hitherto, and the extensions and modernization have consequently made possible an appropriate and overdue expansion of the content of the syllabus. Moreover, in formulating educational policy, the intentions of the Ministry with respect to academic status have been observed in that plans have been made to bring by stages the level of instruction up to that of a university.

The material facilities the College possesses are unique in so far as that, for practical instruction, they include complete yards for the manufacture of all types of leather, which are made by students working independently, under supervision, as part of their course. The layout has been planned to simulate ideal tannery conditions, and the machinery and other equipment, much of it supplied on permanent loan by the makers, is of the latest design. It will be possible to process twelve hides per week, and in the more flexible conditions of light-leather manufacture, at least twelve dozen skins, by any of the commercial-and many of the experimental-techniques available. A further feature of this department is a complete set of new drying cabinets controlled for humidity, temperature and air-flow, incorporating devices which have been developed over the past decade. All the practical processing work can be now carried out on the ground-floor, which in effect contains a complete tannery appreciably larger than a typical pilot plant.

The additional laboratory space comprises a newly equipped teaching laboratory for senior students, and a microbiological laboratory. Another laboratory has been furnished for physical testing, and it is hoped that in time this will house the most complete set of apparatus for this purpose in Britain. These are, however, extensions of facilities that existed in the original building. An entirely new addition is a research laboratory, which includes a small laboratory. tannery that is to be used mainly for investigations into variations in the processes of the production of sole leather. 